\title{
Performance of common bean families after different generations under natural selection
}

\author{
Nara Oliveira Silva ${ }^{1}$, Magno Antonio Patto Ramalho ${ }^{1}$, Ângela de Fátima Barbosa Abreu ${ }^{2}$ \\ and José Eustáquio de Souza Carneiro ${ }^{3}$ \\ ${ }^{1}$ Universidade Federal de Lavras (UFLA), Departamento de Biologia, Lavras, MG, Brasil. \\ ${ }^{2}$ Embrapa Arroz e Feijão/UFLA, Departamento de Biologia, Lavras, MG, Brasil. \\ ${ }^{3}$ Universidade Federal de Viçosa, Departamento de Fitotecnia, Viçosa, MG, Brasil.
}

\begin{abstract}
A segregant bulk population derived from a single cross between the Carioca MG cultivar and the ESAL 686 line was used to investigate whether the action of natural selection in the direction required by the breeders and the delaying line extraction would increase the chance of obtaining families with greater grain yield. The populations were advanced from $F_{2}$ to $F_{24}$ and obtained families $F_{2}, F_{8}$ and $F_{24}$ from the plants. These families and their parents were assessed for grain yield (kg/ha) in Lavras-MG in three sowing seasons (July 2001, November 2001 and March 2002) in an $18 \times 18$ lattice design with two replications in the first sowing and three in the other two. The largest mean yield, regardless of sowing season, was among the families derived from the $F_{24}$ plants. The frequency of superior families increased when line extraction was delayed to more advanced generations.
\end{abstract}

Key words: Phaseolus vulgaris, common bean, natural selection, bulk breeding method.

Received: June 11, 2003; Accepted: April 26, 2004.

\section{Introduction}

Most economically important traits, such as grain yield, are controlled by many loci whose favorable alleles are dispersed in different lines. Breeding superior lines implies combining the favorable alleles of two or more different lines into a single line. This is obtained through hybridization followed by selfing for some generations until testing to identify the required line.

Decisions such as which parents to hybridize, how to increase homozygosis, how to conduct the segregant populations and/or families must be made by the breeder. There is information in the literature to help with these decisions (Abreu et al., 2002; Carneiro et al., 2002).

Options for population improvement include the bulk method that, although proposed at the start of the $20^{\text {th }}$ century, is still one of the most efficient methods. In this method, the plants are harvested in bulk starting from the $F_{2}$ generation to obtain the next generation. This procedure is repeated for three or four generations until most of the loci are in homozygosis. The families are then obtained and more intense artificial selection is started (Ramalho et al., 2001).

Send correspondence to Nara Oliveira Silva. Universidade Federal de Lavras, Departamento de Biologia, Caixa Postal 37, 37200-000 Lavras, MG, Brazil. E-mail: nara@ufla.br.
A question that arises from the use of this method is whether natural selection acts to preserve the individuals that are desired by the breeders, for example, the top yielding ones. Studies have been carried out in barley using a mixture of pure lines (Allard, 1999) and segregant populations (Soliman and Allard, 1991). Similar studies were also performed in common bean (Gonçalves et al., 2001, Corte et al., 2002). In all cases natural selection acted towards increasing the yield of segregant populations.

Selfing gradually releases the variability in a predictable way. However, this release is more intense until $F_{5}$ when the additive genetic variance $\left(\sigma_{\mathrm{A}}^{2}\right)$ is 1.875 greater than that of the $\mathrm{F}_{2}$ generation. Variability is still released beyond this generation but at a slower rate until reaching $2 \sigma_{A}^{2}$ in the $\mathrm{F}_{\infty}$ generation (Ramalho et al., 1993). Therefore, there is no theoretical justification to delay line extraction beyond the $\mathrm{F}_{5}$ generation, as the variability released is not worth the extra time spent. However, there is still the question of whether natural selection is efficient for selecting superior lines as has been shown in population performance studies and whether longer delays in lines extraction from the bulk population are justified. Unfortunately no information regarding this issue is available in the literature.

The present study was carried out to investigate whether natural selection increases the chance of obtaining higher yielding families in common bean and justify delay- 
ing line extraction from bulk populations beyond the generation recommended by quantitative genetics.

\section{Material and Methods}

The experiments were conducted in two locations: a) Lavras County in Southern Minas Gerais state, in the experimental area of the Department of Biology (DBI) of the Universidade Federal de Lavras (UFLA) at $910 \mathrm{~m}$ altitude, $21^{\circ} 45^{\prime} \mathrm{S}$ latitude and $45^{\circ} 00^{\prime} \mathrm{W}$ longitude; and b) in Ijaci County, also southern Minas Gerais State, at $920 \mathrm{~m}$ altitude, $21^{\circ} 14^{\prime}$ S latitude.

A common bean segregant population derived from the cross between the Esal 686 line (early with determined type I growth habit, large grains, yellow tegument, and high pod resistance to Phaeoisariopsis griseola) and the Carioca MG cultivar (normal cycle, undetermined type II growth habit, small grains and cream, brown striped tegument and susceptibility to Phaeoisariopsis griseola) was used for the studies. Crossing these two parents and advancing homozygosis from the $\mathrm{F}_{2}$ to the $\mathrm{F}_{24}$ generation using the bulk method were carried out by Corte et al. (2002). In each generation, the seeds were bulked after harvesting and then divided in two quantities: a) one for storage in a cold chamber; and, b) the other for sowing the next generation.

The $\mathrm{F}_{2}, \mathrm{~F}_{8}$ and $\mathrm{F}_{24}$ segregant populations were sown in March 2001 and $108 \mathrm{~F}_{2: 3}, 107 \mathrm{~F}_{8: 9}$ and $107 \mathrm{~F}_{24: 25}$ families were obtained at harvest. These families and the parents were assessed for grain yield per plot in July of 2001 in an $18 \times 18$ simple lattice design experiment sown in July at Ijaci. Plots were formed by an $1.5 \mathrm{~m}$ single row with a density of 15 seeds per linear meter. Row spacing was $0.5 \mathrm{~m}$. During the experiment, $400 \mathrm{~kg} / \mathrm{ha}$ of an 8-28-16 formula fertilizer were applied at sowing and $150 \mathrm{~kg} / \mathrm{ha}$ of ammonia sulfate were applied as side dressing 20 days after emergence. Weekly supplementary irrigations of approximately $25 \mathrm{~mm}$ were applied during the dry periods. Plants were kept free from weed competition using pre- and postemergence herbicides. Diseases and pests were not controlled.

In November of 2001 and in March of 2002 there were two more evaluations. An 18 x 18 lattice design with three replications was used in these two sowing seasons. Plots consisted of two $2 \mathrm{~m}$ rows spaced at $0.5 \mathrm{~m}$ with 15 seeds per meter density. The management practices were the same as those used in the wet season and the trait assessed was also grain yield per plot.

The grain yield data $(\mathrm{kg} / \mathrm{ha})$ were first submitted to individual (per experiment) analysis of variance. Based on expected mean squares, the estimates of genetic and phenotypic variances among family averages were obtained. Broad sense heritability $\left(\mathrm{h}_{\mathrm{i}}^{2}\right)$ was estimated using the Vencovsky and Barriga (1992) methodology. Upper and lower limits of confidence intervals at $1-\propto=0.95$ probability level were estimated for heritabilities (Knapp et al., 1985).

After checking for homogeneity of variances, a joint analysis of variance was performed with the adjusted means, considering all except the mean and generation as random effects. The family genetic variance, free from the interaction effect, was obtained, using a procedure similar to that presented by Ramalho et al. (2000), i.e., from the estimated covariance between the mean performances of the families taking pairs (xy) of sowing seasons. The average of the three values obtained was taken as the genetic variance $\left(\overline{\operatorname{Cov}}_{\mathrm{G}_{\mathrm{xy}}}=\hat{\sigma}_{\mathrm{G}}^{2}\right)$.

\section{Results and Discussion}

As already mentioned, the segregant population from which the families were derived was obtained from the cross between the ESAL 686 x Carioca MG lines. These parents were chosen because of their distinct life cycle, grain size and growth habit, which in principle are traits that are greatly affected by the action of natural selection and, therefore, suitable for the objective of this study. It is important to emphasize that the action of natural selection on the previously mentioned traits was investigated by Gonçalves et al. (2001).

In the joint analysis of variance (Table 1), significant differences were observed $(p \leq 0.01)$ for all sources of variation, except for parents and the interaction families $\mathrm{x}$ controls $\mathrm{x}$ sowing season. The significant families $\mathrm{x}$ sowing season interaction indicated that the family performance was not similar in the different sowing seasons. As the environmental conditions among the sowing seasons are very distinct and there is difference among the families, it is expected that they respond differently to the environmental variation. The occurrence of genotype $\mathrm{x}$ sowing season interaction in common bean is commonly reported in the literature (Abreu, 1990; Ramalho, Abreu et al., 1993; Gonçalves, 1995; Ramalho et al., 1998). One of the most expressive results in Table 1 is the significance of the $F$ test ( $p \leq 0.05)$ for family type, indicating that the mean yield varied according to the generation of the plant that originated the families. Table 2 shows that the largest mean yield was observed, regardless of sowing season, in the $\mathrm{F}_{24}$ derived families, which were $20 \%$ higher yielding than the $\mathrm{F}_{2}$ derived families.

Since the interaction among family types $\mathrm{x}$ sowing seasons was significant $(\mathrm{p} \leq 0.01)$, it was ascertained whether these previous results were consistent among sowing seasons. It was observed that in spite of the significant interaction, the mean yield of the $F_{2}$ derived families was lower than that of the $\mathrm{F}_{24}$ derived families in all sowing seasons (Table 2).

Opposite behavior was expected in the presence of dominance, that is, a reduction in the yield mean with selfing due to a $50 \%$ reduction in heterosis in each genera- 
Table 1 - Summary of the joint analysis of variance for yield $(\mathrm{kg} / \mathrm{ha})$ of families derived from $\mathrm{F}_{2}, \mathrm{~F}_{8}$ and $\mathrm{F}_{24}$ plants in three sowing seasons, July/2001, November/2001 and March/2002.

\begin{tabular}{|c|c|c|}
\hline Source of variance & Degrees of freedom & Mean square \\
\hline Sowing season & 2 & $2269418299.00 * *$ \\
\hline Families & 323 & $1702174.44 * *$ \\
\hline Among families & 2 & $2308505.67 *$ \\
\hline Among $\mathrm{F}_{2}$ families & 107 & $1584773.61^{* *}$ \\
\hline Among $\mathrm{F}_{8}$ families & 106 & $1463108.43^{* *}$ \\
\hline Among $\mathrm{F}_{24}$ families & 106 & $932455.92 * *$ \\
\hline Among controls & 1 & 558464.19 \\
\hline Families $v s$. controls & 1 & $61717697.94 * *$ \\
\hline Families vs. sowing season & $433^{1 /}$ & $1001640.10^{* *}$ \\
\hline Among families $v s$. sowing season & 4 & $2093719.94 * *$ \\
\hline Among families $\mathrm{F}_{2} v \mathrm{~s}$. sowing season & $145^{1 /}$ & $1124010.24 * *$ \\
\hline Among families $\mathrm{F}_{8} v s$. sowing season & $153^{1 /}$ & $1117995.14^{* *}$ \\
\hline Among families $\mathrm{F}_{24} v s$. sowing season & $214^{1 /}$ & $746758.32 * *$ \\
\hline Families vs. controls $v s$. sowing season & 2 & 294618.15 \\
\hline Among controls vs. sowing season & 2 & 1114870.9 \\
\hline Mean effective error & $443^{1 /}$ & 424482.6 \\
\hline Mean & & 2862.7 \\
\hline Coefficient of variation (\%) & & 21.80 \\
\hline
\end{tabular}

1/ Degrees of freedom were adjusted by the COCKRAN (1954) method.

tion. Actually, although some studies have detected dominance in common bean (Nienhuis and Singh, 1988), most studies have shown the predominance of additive allelic action (Abreu et al., 2002). In this case, the means should not change with selfing.

Therefore, ruling out sampling problems that did not occur in this situation, natural selection explains best the increase in the means of the derived lines. Natural selection preserved the best-adapted individuals (higher yielding), which left more descendents as shown by Darwin at the end of the $19^{\text {th }}$ Century, during selfing the bulk populations (Ramalho et al., 2000). This fact was previously detected in

Table 2 - Average of grain yield means $(\mathrm{kg} / \mathrm{ha})$ of the $\mathrm{F}_{2}, \mathrm{~F}_{8}$ and $\mathrm{F}_{24}$ derived families and the parents in three sowing seasons July/2001, November/2001 and March/2002.

\begin{tabular}{lccccc}
\hline & \multicolumn{3}{c}{ Sowing season } & & \\
\cline { 2 - 4 } Families & July/2001 & $\begin{array}{r}\text { Novem- } \\
\text { ber/2001 }\end{array}$ & $\begin{array}{c}\text { March/20 } \\
02\end{array}$ & Mean & $\%$ \\
\hline $\mathrm{F}_{2}$ & 4418 & 1241 & 2255 & 2638 & 92.30 \\
$\mathrm{~F}_{8}$ & 4682 & 1325 & 2331 & 2779 & 97.23 \\
$\mathrm{~F}_{24}$ & 4961 & 1853 & 2659 & 3158 & 110.50 \\
\hline Mean & 4687 & 1473 & 2415 & 2858 & 100.00 \\
Parents & & & & & \\
Carioca MG & 6061 & 1782 & 2472 & 3438 & 105.85 \\
ESAL 686 & 4641 & 1682 & 2850 & 3058 & 94.15 \\
Mean & 5351 & 1732 & 2661 & 3248 & 100.00 \\
\hline
\end{tabular}

the same population when the mean performance of the segregant populations was assessed (Corte et al., 2002; Gonçalves et al., 2001). Similar results have also been observed in other species (Allard, 1999).

The grain yield frequency distribution shown in Figure 1 indicated the presence of among family variability, which confirmed the among family differences detected in the $F_{2}, F_{8}$ and $F_{24}$ derived generations. It is evident that the frequency distribution of the $\mathrm{F}_{24}$ families showed greater asymmetry in the direction of larger mean yield as expected from the previous commentaries.

The additive genetic variability is gradually released in the selfing generations. The additive variance among families derived from $\mathrm{F}_{2}$ and $\mathrm{F}_{8}$ plants is equal to $1.0 \sigma_{\mathrm{A}}^{2}$ and $1.99 \sigma_{\mathrm{A}}^{2}$, respectively. Among the families derived from $\mathrm{F}_{24}$ plants the increase is very small to $1.999 \sigma_{\mathrm{A}}^{2}$, and in the $\mathrm{F}_{\infty}$ generation it is $2.0 \sigma_{\mathrm{A}}^{2}$. Therefore, it is expected that the among family additive variance increased over the selfing series to the limit of twice that present among $\mathrm{F}_{2}$ plants. However, the estimates from the joint and individual analyses presented in Table 3 showed that, contrary to expectations, the genetic variance among families derived from $\mathrm{F}_{2}$ plants was almost always greater than those derived from $\mathrm{F}_{24}$ plants. This result can only be explained by sampling variation or, more likely, to the action of natural selection (Allard, 1999). If natural selection acts, it will gradually use the variability released by selfing and, under this condition, the mean yield increases and the available variability decreases as was observed. 

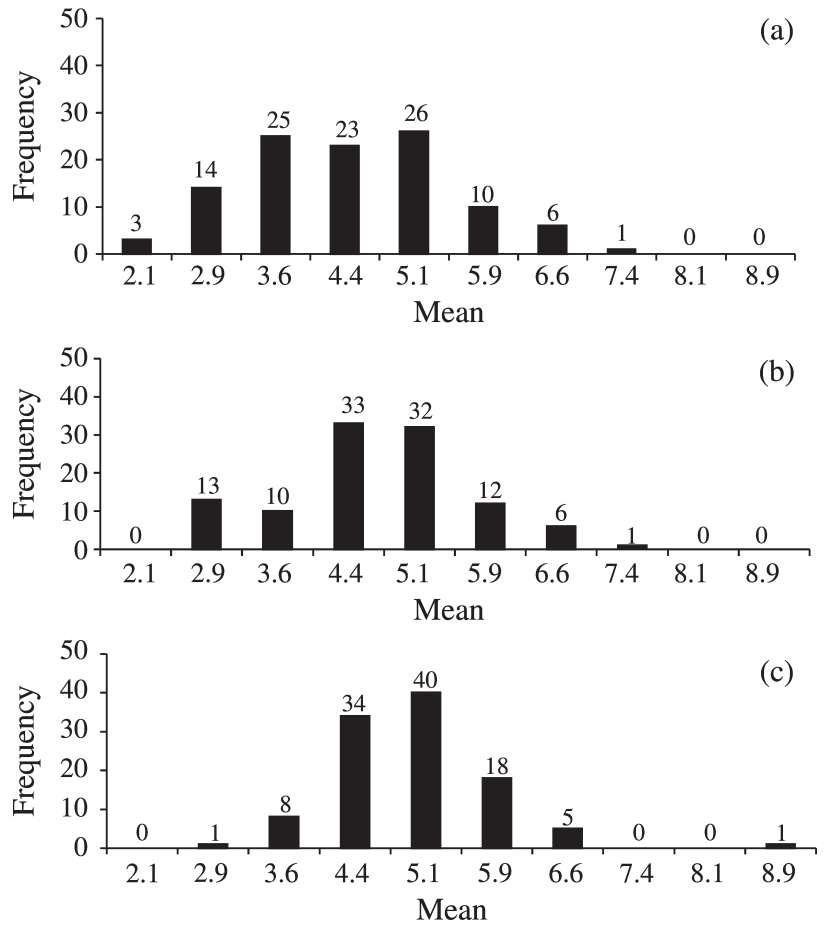

Figure 1 - Frequency distribution of the grain yield means in $t /$ ha of the families derived from $\mathrm{F}_{2}$ (a), $\mathrm{F}_{8}$ (b) and $\mathrm{F}_{24}$ (c) plants. Average of three sowing seasons.

Table 3 shows the estimates of genetic variance for sowing season $\left(\hat{\sigma}_{\mathrm{G}_{\mathrm{Fi}}}^{2}\right)$ and in joint analysis $\left(\overline{\operatorname{Cov}}_{\mathrm{G}_{\mathrm{xy}}}=\hat{\sigma}_{\mathrm{G}}^{2}\right)$, and broad sense heritability $\left(\hat{\mathrm{h}}_{\mathrm{m}}^{2}\right)$. A decrease in the genetic variance was observed in the winter sowing season with the advance of selfing. The heritability that is directly proportional to the genetic variance also decreased. This fact reinforced the previous discussion on natural selection acting to screen out less adapted individuals (lower yielding) and
Table 4 - Mean grain yield ( $\mathrm{kg} / \mathrm{ha})$ of the best performing 30 families.

\begin{tabular}{|c|c|c|c|c|c|}
\hline Families & Mean ${ }^{1 /}$ & Origin & Families & Mean ${ }^{1 /}$ & Origin \\
\hline 1 & 3734 & $\mathrm{~F}_{24}$ & 16 & 3527 & $\mathrm{~F}_{24}$ \\
\hline 2 & 3725 & $\mathrm{~F}_{24}$ & 17 & 3525 & $\mathrm{~F}_{24}$ \\
\hline 3 & 3704 & $\mathrm{~F}_{2}$ & 18 & 3518 & $\mathrm{~F}_{2}$ \\
\hline 4 & 3694 & $\mathrm{~F}_{24}$ & 19 & 3510 & $\mathrm{~F}_{24}$ \\
\hline 5 & 3609 & $\mathrm{~F}_{8}$ & 20 & 3506 & $\mathrm{~F}_{24}$ \\
\hline 6 & 3585 & $\mathrm{~F}_{24}$ & 21 & 3500 & $\mathrm{~F}_{24}$ \\
\hline 7 & 3570 & $\mathrm{~F}_{8}$ & 22 & 3495 & $\mathrm{~F}_{24}$ \\
\hline 8 & 3562 & $\mathrm{~F}_{24}$ & 23 & 3489 & $\mathrm{~F}_{2}$ \\
\hline 9 & 3550 & $\mathrm{~F}_{24}$ & 24 & 3734 & $\mathrm{~F}_{24}$ \\
\hline 10 & 3549 & $\mathrm{~F}_{8}$ & 25 & 3725 & $\mathrm{~F}_{24}$ \\
\hline 11 & 3547 & $\mathrm{~F}_{24}$ & 26 & 3704 & $\mathrm{~F}_{2}$ \\
\hline 12 & 3539 & $\mathrm{~F}_{2}$ & 27 & 3694 & $\mathrm{~F}_{24}$ \\
\hline 13 & 3535 & $\mathrm{~F}_{8}$ & 28 & 3609 & $\mathrm{~F}_{8}$ \\
\hline 14 & 3533 & $\mathrm{~F}_{8}$ & 29 & 3585 & $\mathrm{~F}_{24}$ \\
\hline 15 & 3532 & $\mathrm{~F}_{24}$ & 30 & 3570 & $\mathrm{~F}_{8}$ \\
\hline
\end{tabular}

${ }^{1}-\mathrm{F}_{24}$ derived families corresponded to $60 \%$ of them, $\mathrm{F}_{8}$ corresponded to $23.33 \%$ of them and $\mathrm{F}_{2}$ corresponded to $16.67 \%$ of them.

therefore reducing the variability released among the assessed families by selfing.

Table 4 shows the 30 families with largest yield mean in the three sowing seasons. It is clear that among the better performing families there is a predominance of those derived from $\mathrm{F}_{24}$ plants $(60 \%)$, that is, of those submitted to a greater number of cycles under the action of natural selection. This observation reinforced the hypothesis of the efficiency of natural selection during the population generation advance by the bulk method. Only five families of the 30 best $(16.67 \%)$ were derived from the $\mathrm{F}_{2}$ generation. It has also been reported that the action of natural selection con-

Table 3 - Estimate of the genetic variance for sowing season $\left(\hat{\sigma}_{\mathrm{G}_{\mathrm{Fi}}}^{2}\right)$ and in joint analysis $\left(\overline{\operatorname{Cov}}_{\mathrm{G}_{\mathrm{xy}}}=\hat{\sigma}_{\mathrm{G}}^{2}\right)$, broad sense heritability $\left(\hat{\mathrm{h}}_{\mathrm{m}}^{2}\right)$ and variance of the interaction families $x$ sowing season $\left(\hat{\sigma}_{\mathrm{G}_{\mathrm{F}} \mathrm{X}}^{2}\right)$ for derived families of plants $\mathrm{F}_{2}\left(\mathrm{~F}_{2: 3}, \mathrm{~F}_{2: 4}\right.$ and $\left.\mathrm{F}_{2: 5}\right), \mathrm{F}_{8}\left(\mathrm{~F}_{8: 9}, \mathrm{~F}_{8: 10}\right.$ and $\left.\mathrm{F}_{8: 11}\right)$ and $\mathrm{F}_{24}\left(\mathrm{~F}_{24: 25}, \mathrm{~F}_{24: 26}\right.$ and $\left.\mathrm{F}_{24: 27}\right)$.

\begin{tabular}{|c|c|c|c|c|}
\hline \multirow[t]{2}{*}{ Estimates } & \multirow[b]{2}{*}{ Joint } & \multicolumn{3}{|c|}{ Sowing season } \\
\hline & & July/2001 & November/2001 & $\operatorname{March} / 2002$ \\
\hline$\hat{\sigma}_{\mathrm{G}_{\mathrm{F} 2}}^{2}$ & $59,729.25 \pm 21,863.27^{1 /}$ & $699,425.19$ & $126,115.19$ & $82,489.63$ \\
\hline$\hat{\sigma}_{\mathrm{G}_{\mathrm{F} 8}}^{2}$ & $44,737.40 \pm 26,999.49$ & $382,614.78$ & $220,418.07$ & $248,586.84$ \\
\hline$\hat{\sigma}_{\mathrm{G}_{\mathrm{F} 24}}^{2}$ & $24,072.18 \pm 11,148.96$ & $137,440.68$ & $115,417.82$ & $94,670.37$ \\
\hline$\hat{\mathrm{h}}_{\mathrm{mF}_{2}}^{2}(\%)$ & $29.07(0.48-48.52)^{2 /}$ & $57.82(41.54-68.86)$ & $77.69(69.67-83.09)$ & $63.13(49.86-72.06)$ \\
\hline$\hat{\mathrm{h}}_{\mathrm{mF}_{\mathrm{g}}}^{2}(\%)$ & $23.59(0.00-44.62)$ & $42.86(20.69-57.85)$ & $85.89(80.79-89.32)$ & $83.76(77.89-87.71)$ \\
\hline$\hat{\mathrm{h}}_{\mathrm{mF}_{24}}^{2}(\%)$ & $19.91(0.00-41.96)$ & $21.22(0.00-41.90)$ & $76.12(67.48-81.92)$ & $66.27(54.08-74.47)$ \\
\hline$\hat{\sigma}_{\mathrm{G}_{\mathrm{F} 2} \mathrm{XS}}^{2}$ & $272,041.53$ & - & - & - \\
\hline$\hat{\sigma}_{\mathrm{G}_{\mathrm{FB}} \mathrm{XS}}^{2}$ & $269,702.29$ & - & - & - \\
\hline$\hat{\sigma}_{\mathrm{G}_{\mathrm{F} 24} \times \mathrm{S}}^{2}$ & $125,330.82$ & - & - & - \\
\hline
\end{tabular}

1/ Corresponding to variance of variance.

2/ Lower and upper limit of the heritability estimate. 
tributed to preserve the best-adapted individuals (higher yielding) in crops such as in Triticum aestivum L (Gregan and Busch, 1978) Phaseolus lunatus L. (Tucker and Harding, 1974) and Phaseolus vulgaris L. (Pirola et al., 2002).

All these results pointed towards the efficiency of the bulk method. It was easy to perform, enabled the action of natural selection and, further, allowed a delay in line extraction without loss for the breeder. According to the results from this study, the delay in line extraction can even provide genetic gains for grain yield above those that could be obtained by the breeder himself. It is pointed out, however, that this population had wide variability for cycle, grain size and growth habit. It could be asked whether the same result would be obtained with less divergent populations. It is pointed out that the action of natural selection on the traits by which the parents differed was very fast. From $\mathrm{F}_{5}$ onwards, practically no plants with determined habit, early cycle and with very large grains were detected (Gonçalves et al., 2002). Therefore, it is expected that these results can be extrapolated to other segregant populations. However, if the objective of the program is to select plants with determinate growth habit or large seeds in populations from crosses of contrasting parents for these traits, plants with determinate habit and/or large seeds should be selected from the $\mathrm{F}_{2}$ onwards. The obtained population could then be advanced by the bulk method to allow for natural selection on the other traits. On the other hand, although the parents were different for the mentioned traits, no difference was detected in grain yield, a trait on which natural selection acted in the present case.

\section{Acknowledgments}

Research was supported by Conselho Nacional de Desenvolvimento Científico e Tecnológico (CNPq), Minas Gerais, Brazil.

\section{References}

Abreu A de FB, Ramalho MAP and Santos JB (2002) Prediction of seed-yield potential of common bean populations. Genetics and Molecular Biology 25:323-327.

Allard RW (1971) Princípios do Melhoramento Genético de Plantas. Edgard Blucher, São Paulo, 381 pp.

Allard RW (1999) Principles of Plant Breeding. 2nd edition. John Wiley \& Sons, New York, 254 pp.
Carneiro JE de S, Ramalho MAP, Abreu A de FB and Gonçalves FMA (2002) Breeding potential of single, double and multiple crosses in common bean. Crop Breeding and Applied Biotechnology 2(4):515-524.

Cochran WG (1954) The combination of estimates from different experiments. Biometrics 10:101-129.

Corte HR (1999) Comportamento de populações segregantes de feijão, avançadas pelo método do "Bulk", por dezessete gerações. Dissertação de Mestrado, Universidade Federal de Lavras, Lavras.

Corte HR, Ramalho MAP, Gonçalves FMA and Abreu A de FB (2002) Natural selection for grain yield in dry bean populations bred by the bulk method. Euphytica 123:287-393.

Gonçalves FMA, Ramalho MAP and Abreu A de FB (2001) Natural selection in four common bean traits. Crop Breeding and Applied Biotechnology 1:213-220.

Gregan PB and Busch RH (1978) Effects of natural selection and the relationship of leaf traits with yield in hard red spring wheat crosses. Crop Science 18:1021-1025.

Nienhuis J and Singh SP (1988) Genetic of seed yield and its components in common bean (Phaseolus vulgaris L.) of Middle - American origins. I. General combining ability. Plant Breeding 101:143-154.

Pirola LH, Ramalho MAP, Carneiro JE de S and Abreu A de FB (2002) Natural selection and family $x$ location interaction in the common (dry) bean plant. Genetics and Molecular Biology 25:343-347.

Ramalho MAP, Abreu A de FB and Santos JB dos (2001) Melhoramento de espécies autógamas. In: Nass LL, Valois ACC, Melo IS de and Valadares-Inglis MC (eds) Recursos Genéticos e Melhoramento - Plantas. Fundação MT, Rondonópolis, pp 201-230.

Ramalho MAP, Abreu A de FB and Santos PSJ dos (1998) Interações genótipos x épocas de semeadura, anos e locais na avaliação de cultivares de feijão nas regiões Sul e Alto Paranaíba em Minas Gerais. Ciência e Agrotecnologia 22:176-181.

Ramalho MAP, Ferreira DF and Oliveira AC (2000) Experimentação em genética e melhoramento de plantas. UFLA, Lavras, 326 pp.

Ramalho MAP, Santos JB dos and Zimmermman MJ de O (1993) Genética quantitativa em plantas autógamas: Aplicações ao melhoramento do feijoeiro. UFG, Goiânia, 271 pp.

Soliman KM and Allard RW (1991) Grain yield of composite cross populations of barley: Effects of natural selection. Crop Science 31:705-708.

Tucker CL and Harding J (1974) Effect of the environment on seed yield in bulk populations of lima beans. Euphytica 23:135-139.

Associate Editor: Márcio de Castro Silva Filho 